\title{
EGALITARIAN DEMOCRACY BETWEEN ELITISM AND POPULISM
}

\author{
IVAN CEROVAC \\ University of Trieste, Department of Humanities \\ Piazzale Europa 1, 34127 Trieste, Italy \\ E-mail address: ivan.cerovac@phd.units.it
}

\begin{abstract}
In his influential book Disagreement: Politics and Philosophy Jacques Ranciere builds a substantial critique of liberal regimes present in most Western countries. He finds them defective because: (1) they allow wealth and economic power of groups and individuals to influence public decision-making, making those with economic power an elite group; (2) they allow knowledge and expertise of groups and individuals to influence public decision-making, making those with epistemic power an elite group; (3) they allow and encourage social and economic conditions that make people inappropriate for decision-making on important issues, making those with certain characteristics thus acquired an inferior group. We focus on the Ranciere's second objection by relying on Estlund's epistemic proceduralis approach and claim that one does not have to embrace postmodernist idea of reducing reason to relations of power in order to present a substantial critique of our contemporary society. Furthermore, we argue that one does not have to base egalitarian democracy on postmodernist ideas that reject the truth-tracking potential of democratic procedures - egalitarian democracy is perfectly compatible with the idea of truth in politics.
\end{abstract}

Keywords: Ranciere, democratic legitimacy, elitism, populism, epistemic proceduralism, deliberative democracy

\section{INTRODUCTION}

Contemporary debates on democracy as a method of collective decision making characterized by a kind of equality among the participants contrast two opposing approaches. The first deploys a pessimistic account of a democratic man as a mostly unreasonable being, inappropriate for decision-making about important questions. Since people want our public decisions to display some sort of epistemic quality (people want them to be correct, justified or just), people should emphasize the role of experts in a decision-making process. This approach, typically referred to as elitism, advocates for a kind of government that will get the most possible out of the fact of democracy, but will also contain it to protect the government of the best (Ranciere, 2009). The second 
approach deploys an optimistic account of a democratic man as a being impersonating a variety of civil and political virtues, fully capable of making serious political decisions. Since we do not want to be ruled by others, we want to have an equal chance as other members of our community to influence the decisions that affect our well-being. This approach, typically referred to as populism, advocates a kind of government that will put a greater emphasis on direct political participation of all citizens, arguing that public decisions should be the result of the struggle of forces exerted directly or indirectly by large populations (workers, retirees, consumers).

In his influential books Hatred of Democracy and Disagreement: Politics and Philosophy Jacques Ranciere builds a substantial critique of liberal regimes present nowadays in most Western countries. Democracy, as we have indicated earlier, represents an idea of free and equal people making collective decisions that are binding on all members of the group. If people participate in the decision-making process as equals, then every person should have an equal chance of influencing the final decision. This is how democracy was understood in ancient Greece, where public functions were to be arranged according to lot, since the dice would give equal chances to everyone.

This was also an idea that Plato so rapturously criticized as being self-defeating (Ranciere, 1998). It is clear, however, that nowadays not every person has an equal chance of influencing the final outcome of a decision-making process. Institutions and instruments of contemporary liberal democracies strongly favor the elitist approach; the social power is removed from the people and transferred to intellectual and economic elites. To make it even worse, these very elites display a specific kind of hatred towards democracy, advocating to an even greater extent the idea that people should be excluded from decision-making process about numerous public issues. They believe that there is only one good democracy, the one that keeps people as far as possible from decision-making processes.

J. Ranciere's argument cannot be easily reproduced in the standard fashion of analytic philosophy. However, in this paper we want to emphasize and discuss a few points that might represent some premises of the argument J. Ranciere deploys in his books.

According to J. Ranciere, contemporary liberal democracies are not democracies at all - they are governed by a representation of minorities who are entitled to take charge of public affairs (Ranciere, 2009). They have oligarchic form and rely on popular acceptance of a rule by a minority group that has succeeded in representing itself as the elite. Ranciere criticizes "an oligarchic alliance of wealth and science [that] stakes a claim to all the power" (Ranciere, 2009, p. 78), thus negating the idea of equality and the basic principle of democracy. The fairness of decision-making process, represented by the equality of all participants, is no longer the key feature that defines the good governance (though it should be for every democratic system); instead, the quality of decisions is introduced as a second feature that defines the good governance, and since it is assumed that not everyone can to an equal extent contribute and bring about good decisions, not everyone should have equal chances to influence the final outcome in a decision-making process. To make it even worse, this alliance has produced and is still producing social and economic conditions that shape democratic man as a being of excesses, as an insatiable devourer of commodities, that only enforces and confirms the elitist idea of people as inappropriate for decision-making on important public issues. 
Contemporary liberal democracies are thus defective because:

1) they neglect the importance of procedural fairness and put emphasis on the quality of decisions made, thus justifying unequal distribution of political power;

2) they allow wealth and economic power of groups and individuals to influence public decision-making, making those with economic power an elite group;

3) they allow knowledge and expertise of groups and individuals to influence public decision-making, making those with epistemic power an elite group;

4) they allow and encourage social and economic conditions that make people inappropriate for decision-making on important issues, making those with certain characteristics thus acquired an inferior group ${ }^{1}$.

I agree with most points J. Ranciere made, though with some modifications and not to the same extent. What we reject is his idea that quality of outcomes as a feature used to evaluate the political system is incompatible with democracy (1), as well as his pessimistic claim that representative liberal democracy cannot be improved to answer objections (2) to (4). Unlike J. Ranciere, who emphasizes that "unequal society does not carry any equal society in its womb" (Ranciere, 2009, p. 96), we believe that liberal democracy can break the link between economic and political power, as well as to cultivate certain political and participatory virtues amongst its citizens.

We are not going to answer all the objections J. Ranciere made. Instead, we want to focus on the problems regarding the relationship between epistemology and democracy, i.e. on objections (1) and (3) raised by J. Ranciere. One can clearly see that these critiques are related; in order to claim that knowledge and expertise should not bear additional political power, J. Ranciere has to assume that the quality of decisions should not influence their legitimacy nor the legitimacy-generating potential of the political system that produced them. This is why one first has to demonstrate that some form of quality of decisions is indeed necessary for political legitimacy in order to oppose J. Ranciere's thoughts on the role of experts in political decision-making.

In the first section of this paper we briefly sketch the main idea underlying J. Ranciere's critique of modern democracies. We distinguish two main values used to justify the legitimacy of any political system: fairness of a procedure (proceduralism) and the quality of outcomes (instrumentalism). J. Ranciere clearly adopts a form of proceduralism, since he perceives democracy as a good form of government as long as it adopts a fair decisionmaking procedure (every person has an equal chance to participate in a decision-making process), regardless of the outcomes thus created. Plato, on the other hand, adopts a form of instrumentalism, since for him a certain system represents a good form of government as long as it produces good outcomes, regardless of a procedure used to produce these decisions. In the final parts of this section we argue that a dualistic approach is both possible and desirable; we should focus on both procedural and instrumental values in order to define what a good form of government is (answer to Ranciere's first objection).

In the next section we refer to the related objection against liberal democracy - its inability to separate political from epistemic power. Unlike J. Ranciere, we embrace the

\footnotetext{
Though it might appear that J. Ranciere displays this view only from the standpoint of "those who hate democracy", it seems to me that he is deeply concerned with the effect consumerist society has on people's ability to participate in collective decision-making. "[...] The multitude, freed of the worry of governing, is left to its private and egoistical passions. Either the individuals composing it are uninterested for public matters and abstain from elections; or they approach them uniquely from the point of view of their interests and consumer whims" (Ranciere, 2009, p. 75).
} 
idea that there is truth in politics, as well as the idea that there are some people (experts) who can acquire true beliefs easier than other members of the community. However, following David Estlund, we claim that mere epistemic superiority does not generate legitimacy to rule over others. Decision-making procedure must be designed to promote both procedural fairness and epistemic quality of the decisions made (Estlund, 2009a). We should adopt a form of deliberative democracy that will tend to produce correct decisions, and therefore it must rely on the knowledge by experts. However, following Matthew Festenstein, we believe that popular control over experts can still exist without endangering the idea of democratic equality (Festenstein, 2009) (answer to Ranciere's third objection).

\section{BETWEEN FAIRNESS AND TRUTH}

When we try to justify any form of government we generally start from its virtues, and contemporary debates in political philosophy have divided these virtues in two groups: procedural and non-procedural. As the name suggests, the procedural virtues of some form of government are based on the procedure that is used to bring about political decisions - they are not related to the quality of the decisions, but to the process by which these decisions are made. The main procedural virtue of democracy is its tendency to treat all participants in the decision making process equally and that gives everyone an equal chance to influence the final decision. Non-procedural qualities are not related to the decision making process, but to the quality of the decisions created. In other words, they do not arise from the procedure by which the decision was made, but from the outside world in which the decision proves to be profitable or unprofitable, right or wrong, true or false (this is why non-procedural virtues are often, but not necessarily, also called epistemic virtues).

All positions that appear in the debate on the justification of democracy base their arguments on these virtues, although we can rightly distinguish monistic (which refer to only one type of virtue) and non-monistic (which justify the authority and legitimacy of democracy by relying on both procedural and on non-procedural virtues) positions. (Christiano, 2004). To get a better insight in the later discussion, we will first briefly examine two basic monistic views.

\section{Instrumentalism.}

Representatives of instrumentalism believe that the correctness and usefulness of political decisions are sufficient conditions to proclaim the political system that produced them to be legitimate. Of course, instrumentalism assumes that there are correct and incorrect decisions and that their accuracy can be determined independently of the procedure by which they are produced. Although this seems like an intuitive assumption (anyone who, according to his own moral judgment, believes that the government has made some wrong decisions, or believes there are moral and immoral actions and that their morality does not depend on the procedure that produced them, implicitly assumes that there are correct and incorrect decisions in politics), there are some theorists who question it, so we shall look briefly at the main objections and show why they do not refute this assumption.

Carl Schmitt, fascist theorist and philosopher, was one of the thinkers who believed that there is no truth and rationality in politics. Politics is considered as the process in which different groups of people compete, stronger groups prevail, and weaker die out 
- in such a process power becomes the right, and the elimination of opponents becomes a good method of political decision making (Schmitt, 1932). Schmitt and other non-cognitivists usually emphasize that truth and politics are conceptually incompatible. Truth obliges us to an ontology of realism, which may be appropriate for science, but it is certainly not for politics - after all, unlike the (natural) sciences, morals and politics are not concerened about any facts that are completely independent of our own perspective.

However, it seems that without truth, no discussion in politics would simply make any sense. Huw Price considers that the debate is impossible without the concept of truth (Price, 2003). Imagine a group of people who accept the standards of honesty and justification of their own opinions, but not the truth. They express their own preferences and desires, but do not think that disagreement means that one of them is wrong. If you do not believe that someone is wrong, we cannot have a discussion - why would we even discuss things with others if we did not believe that our interlocutor is wrong?

Similarly to H. Price, Cherly Misak argues that we cannot conceptually separate the truth from politics. She emphasizes that in morals and politics we distinguish expressions "It seems to me that p" and "I claim that p". By using the first statement we actually try to rid ourselves of the duty to justify our belief, and while using the second statement we are obligated to defend it in a debate with others, and to have good reasons and evidence for $\mathrm{p}$. It is precisely this commitment to justification that makes the constitutive norm of belief - the element that diferenciates belief from other mental states, such as preferences or opinions, is its sensitivity to reasons and evidence (Misak, 2009). Truth is extremely important to us and we cannot make ourselves believe anything without any reason or evidence. Likewise, we believe that political decisions are made on the basis of good or bad reasons, and it is exactly because of these reasons that we think they are (or they are not) correct. We are not ready to leave political decisions to pure chance because we believe that the decision can be correct and incorrect, or true and false.

Plato's epistocracy (the rule by the best, i.e. by those who know, philosophers) can be considered as an example of instrumentalist approach. Plato defines the good governance according to its ability to produce good outcomes and to come to the truth. This is the reason why only the best among us can rule; in order to bring about good and correct decisions, only the most competent citizens should be allowed to participate in the decision-making process. This is what Ranciere sees as Plato's key argument against democracy; it is a self-defeating form of government because, by defining good governance by equality of all participants, it makes it impossible for itself to come to good and correct decisions (what is for Plato the only criteria for justification of a political system) (Ranciere, 2009).

Plato's argument might seem plausible - when we have to make difficult decisions that will influence our future well-being, it is best to accept the advice of experts. If one of us is seriously ill, we should not have a public deliberation and voting in order to determine how we shall treat him. We should instead subdue our judgment to the judgment of an expert (a general physician, or even better, a specialist) and let him decide what to do and what treatment to use. It seems, however, that the physician's right to treat us comes from our consent, and not from his expertise. Political authority simply cannot be derived from expertise! Even if we are ready to embrace the idea that there are good and bad (correct and incorrect) political decisions, as well as the idea that there are people who are experts in certain fields, it does not follow that those who are considered experts should have political authority over others (Rawls, 1999). 
It seems that epistocracy, as well as any other form of government that does not treat people as equals, is incompatible with the idea of people as free and equal. For this reason it cannot be considered as a good form of government; regardless of the outcomes, we want our decision-making procedure to be fair and to treat everyone with equal respect.

Proceduralism.

According to proceduralism, legitimacy of democratic decisions arises from the qualities of procedure. Though it can be used to jusify the rule of a monarch (only decisions produced by monarch are legitimate, regardless of their correctness) or a smaller group of people, it can be made compatible with the idea of people as free and equal when applied to the justification of democracy. Democracy is fair because it gives people the same rights to express their views and influence the final decision. Pure proceduralism can take two forms, justifying aggregative or deliberative democracy. In the case of aggregative democracy, where the basis of the process of democratic decision-making is aggregation of attitudes and preferences, decisions are justified if they were produced by a fair process of aggregation of preferences. Deliberative proceduralism, on the other hand, encourages demoratic deliberation as a decision-making procedure, and every decision produced by a fair deliberative process is considered legitimate.

The result of this process is legitimate regardless of its tendency to be correct according to the procedure-independent standards - its legitimacy lies in the procedural impartiality towards the beliefs and preferences of individuals. Represenatatives of pure proceduralism believe that there are no independent standards that can be used to conclude that some reasons in a public debate are better than others - deep disagreement about the advantages and disadvantages of any decision will always be present. Since there is no way to determine which of the reasons and arguments in the debate are better, we need to give everyone an equal opportunity to influence the final decision.

Ranciere seems to endorse a form of fair (pure) democratic proceduralism: in order to be legitimate, a decision has to be produced by a fair procedure. Going one step further, in order for a procedure to be legitimacy-generating, it has to treat all participants equally, regardless of their expertise, wealth or social status. The quality of outcomes it produces does not affect the legitimacy of the procedure in question. This is why Ranciere so brusquely criticizes modern liberal regimes that try to combine procedure with the quality of outcomes - they favor certain qualities (like expertise or wealth) over others and do not give every participant an equal chance to influence the final decision. His view clearly represents a form of extreme populism.

Lottery (using the dice to determine who will perform certain public duties) is one of the decision-making procedures that Ranciere would accept as adequately democratic (Ranciere, 1998; Kursar \& Vukojević, 2013). Since every participant has an equal chance to be selected, this procedure is undoubtedly fair. But is fairness enough to make it legitimacy-generating?

We must take into account that democracy is not the only fair procedure of public decision-making. If two people have different views, and have to make a decision that will be binding on both, they can simply flip a coin and see which position will prevail. It seems that this is not a good way of making important decisions - however, it is not unjust! The same is true for the distribution of a good: if two people have to share some inheritance, they may agree to flip a coin so that the winner takes it all, and the loser nothing. It seems that this way of decision-making is fair, though poor 
and inappropriate (Estlund, 2009a). If the fairness of a procedure represents a core justification of legitimacy of a decision in question, why should we not (instead of voting) simply flip a coin and see what we should do? Democracy is fair procedure of decision-making because it gives everyone an equal opportunity to influence the final decision, but the same can be said for flipping a coin - everyone has the same the ability to influence the final outcome, i.e. none (Estlund, 1997). Fair proceduralizam thus justifies not only democracy, but coin flipping as well as a proper form of political decision-making. This seems as a conclusion we cannot accept? Why?

The fairness of a procedure ensures that the decision will be produced in a fair way, but it does not ensure that it will necessarily be fair, right or moral. Coin flipping does not provide compelling moral reasons to accept or obey a decision produced in this manner - procedural fairness alone does not give moral legitimacy and authority to the decisions made. Fair proceduralism is insensitive to reasons: it requires from us to give equal weight to the views and interests of all individuals, and never to give priority to one claim over another - even when there is good reason to do so! In an effort to get the views of all individuals treated equally, proceduralism sets too tight constraints, so that nothing can give priority to the attitude of one individual over another, not even good reasons.

Though J. Ranciere's model does not take a form of decision-making based on a coin flip, since we use lot to determine who will receive certain public duties, it is still vulnerable to the objections directed towards pure proceduralism. This idea, considered by David Estlund as queen for a day (Estlund, 1997), does not have a sufficient epistemic appeal to be considered as source of legitimacy. We are not ready to embrace it because we believe that there is an (instrumental) epistemic value in our collective deliberation, and that we can, by exchanging arguments and reasons, and by voting later on the decision we find the best, produce better outcomes than we can by deliberating alone.

There is nothing strange in the fact that we cannot accept coin flipping or queen for a day as good decision-making procedures, although we can agree that they are generally fair models. There must be something else in democracy (something other than fairness), that gives us reasons to accept it and to reject coin flipping and queen for a day. We believe that the decision-making process should be sensitive to reasons, and we want the process to include opinions of other people because in this way it will lead to better solutions than coin flipping or queen for a day. Also, contrary to the ideas of pure deliberative proceduralism, we believe that deliberation improves epistemic value of our decisions, and it is this epsitemic value that represents a necessary part of the democratic authority of the decisions made.

In the end, we are torn between two extremes: on the one hand, we can have some form of elitism - an epistemically reliable decision-making procedure that cannot satisfy the fairness requirement (Mešanović, 2013), and on the other, we can have a sort of populism - a fair decision-making procedure that will be unable to satisfy the correctness requirement (Kursar \& Vukojević, 2013). Is there a middle ground, something that can simultaneously satisfy both conditions?

\section{Epistemic proceduralism.}

The famous non-monistic position that tries to combine fair proceduralism with quality of outcomes is frequently referred to as standard account of epistemic democracy (Cohen, 1986) or epistemic proceduralism (Estlund, 1997). D. Estlund explicitly emphasizes that the first condition for the legatimacy of a particular decision is the 
fairness of the process that produced it. Even if correct, a decision cannot be legitimate unless it is produced by a fair procedure. However, Estlund is aware that alternative institutionalizations of fair process will differ in their truth-tracking potential. He thus claims that a decision is legitimate if it is a product of epistemically the best procedure among those that fall within the set of fair procedures. D. Estlund's view on political legitimacy is clearly non-monistic; in order to be legitimacy-generating, a procedure must have both political and epistemic qualities (Estlund, 2009b).

Unlike instrumentalists, D. Estlund claims that democracy has an intrinsic value (for being a fair procedure), but holds that fairness can be satisfied by various decisionmaking procesures, as well as in various forms of democracy. We are to discriminate among different forms of democracy according to their ability to produce correct outcomes. D. Estlund defends deliberative over aggregative democracy, but the justification he offers for deliberative procedures is instrumental; deliberation is seen as the best means to achieve the desired end - to have correct outcomes in most cases. He thus concludes that only epistemic deliberative democracy can be considered as a legitimacy-generating procedure. Since legitimacy requires procedure that can be both fair and truth-tracking, all other decision-making procedures are excluded as either insufficiently fair or insufficiently epistemic.

In this part of the paper we presented the idea that the correctness of outcomes should not be neglected. We all care about the truth in politics and want to produce decisions that will be correct. J. Ranciere was wrong to exclude truth from politics both fairness and correctness are desirable qualities of a decision-making procedure. However, what if we simply cannot have both? What if Plato is right and our focus on the quality of outcomes is indeed incompatible with political equality? This would force us to choose between the extremes: we could either agree with Plato and claim that we are ready to sacrifice fairness in order to obtain correctness, or we could agree with J. Ranciere and sacrifice correctness in order to obtain fairness of a procedure. In the following part of the paper we want to show that none of these extreme measures are necessary; we can have both correctness and fairness embodied in a single decision-making procedure - epistemic deliberative democracy.

\section{EPISTEMIC DELIBERATIVE DEMOCRACY}

In the former part of this paper we have seen that both fairness and truth-tracking potential are desirable qualities of a decision-making procedure. In this part we analyze Plato's famous objection to democracy, and argue how it can be answered, i.e. how democracy can still have adequate truth-tracking potential by relying on the role of experts in decision-making. This move, however, makes us vulnerable to J. Ranciere's objection that this form of democracy will not be a democracy at all - if we emphasize the role of a certain minority group in a decision-making process, we are endangering the fairness requirement by giving some people greater chance to influence the final outcome. In the rest of this part of the paper we try to answer this objection by further clarifying the role of experts in a democratic decision-making process.

Is it really so that, if we put people to deliberate on important political issues, they will produce correct or semi-correct outcomes? Plato would certainly disagree; in sub-ideal epistemic circumstances, any deliberation is characterized by the fact of widespread incompetence (Prijić-Samaržija, 2013). The majority of people are not only 
inadequately informed, but also not interested in numerous topics, not educated enough to absorb many important issues, not motivated to invest time and cognitive resources or they simply do not have enough time to participate in a public deliberation. Widespread incompetence is a well-documented fact; only $13 \%$ of more than 2000 political questions examined could be answered correctly by $75 \%$ or more of those asked, and only $41 \%$ could be answered by more than half of the public (Delli, 2005). Many of the facts known by a relatively small percentage of the public seem critical for understanding the political world: classic civil liberties, key concepts of political economy, the names of key representatives, basic social indicators and significant public policies etc. Furthermore, informed people in many circumstances refrain from disclosing what they know, either in the light of the informational pressure coming out of whatever happens to be a majority position or the social pressure associated with the risk of social sanctions against dissenters (Sustain, 2006). Using these contemporary results Plato could easily argue that public deliberation will not track the truth. Is there a way to answer Plato's objection and avoid falling back to epistocracy?

There are two possible answers to Plato's challenge; we can either try to reform our society in order to make people more competent and more interested in public issues, or we can try to find an alternative approach that will emphasize the role of experts, but will nonetheless reject epistocracy. These two answers are not mutually exclusive: if we want to keep both qualities of a decision-making procedure, we must improve our decision-making at both fronts (Cerovac, 2013).

The role of experts in the democratic decision-making process. It seems that, contrary to the views of Enlightenment, we rely heavily on others when acquiring knowledge and justifying our beliefs. Even those considered as experts rely on the knowledge of other experts: when scientific studies are performed, there are few experts that can cover all scientific branches prior to what they are dealing with. For example, a general physician is considered an expert in his field, but it is very difficult to say that he knows every detail regarding the production of drugs prescribed to patients. This GP does not know a lot of facts about drugs (especially those facts related to their chemical structure, etc.) - does this mean that he unjustifiably prescribes this drug? It seems that he can still be justified in prescribing the drug though he has not himself investigated all the facts about its production, molecular strucuture etc. It would be impossible for every GP to undertake such a quest for every drug prescribed. Instead, the GP will assess the credibility and sincerity of experts (molecular biologists, chemists) who presented a given thesis about a drug. The same method can be used in democratic deliberation: if we are unable to verify the correctness of a thesis that others introduced into deliberation, we do not discuss directly about the given problems, but about the experts who evaluated them and offered solutions. Following this idea, John $\mathrm{O}^{\prime}$ Neill writes that ,"[he] simply wouldn't know how to appraise the evidence even if we would give him all the detail. [He] wants to know not if the evidence supports this or that conclusion, but whether [he] has good reasons to trust those who offer it" (O'Neill, 2002, p. 259).

This rule extends not only to factual judgments, but also to practical solutions: if we want to assess the quality of certain aspects regarding the functioning of a school, we will have to rely mostly on professional assessment of experts. We can criticize their assessment, but we must bear in mind that we are expected to evaluate the experts, not these aspects of the school themselves (the quality of these aspects of the 
school is evaluated by experts, and it's their job because of the assumption that we are not skilled enough to do so) (Festenstein, 2009). We must bear in mind, however, that sometimes local people will know better than any expert what are the problems of their local community and how to resolve them.

We need, of course, to consider the possibility that sometimes interests of the experts differ from our own. It is possible that the scientists who created the drug have a great interest in public recognition of a drug as safe and ready for sale, or that experts who evaluate the quality of some aspects of a school have an interest to give a negative evaluation so they can he employed to improve its functioning. Accordingly, we need to evaluate not only the competence of those who make a thesis, but also their interest in accepting this thesis. It is not surprising than that trust in politics is very low, and that we are rightly cautious when resolving public issues. However, one should be careful not to exaggerate with caution, since we commit a form of "epistemic injustice" when we do not give someone the credibility that he deserves (Fricker, 2007).

Representatives of epistemic justification of democracy prefer to draw an analogy with the jury - the people who sit on juries are often not adequately educated and are certainly not professionally trained as forensic scientists, forensic psychologists and other experts who can give testimony to the court. Jurors just have to decide which experts and information sources they will believe. In conclusion, though they are not adequately educated to cover various professional issues, jurors usually make correct decisions using the statements of experts who are invited into court. A similar situation occurs with democratic deliberation - although citizens are not expert in numerous public issues, they can make the right decision by avoiding evaluation of certain political decisions (since they are not competent in that area they cannot critically evaluate the reasons, evidence and arguments), but by evaluating the credibility of experts who proposed these decisions (Festenstein, 2009).

Plato's objection based on the fact of widespread incompetence can thus be answered, and political equality preserved. Every participant has an equal chance to influence the final decision (it is not the case that votes by experts are more important than those by nonexperts), and no force except that of the better argument is exercised (Habermas, 1976). Some can, however, question as to whether such an idealized picture can be applied to a contemporary world. In a society characterized by inequality and economic elites that have most of the political power, we should not be surprised to see science being directed to serve interests of the capital and not the interests of the people.

\section{What kind of society can support epistemic proceduralism?}

In this final part of the paper, we want to briefly sketch possible reforms that should be undertaken in order to ensure the success of epistemic proceduralism. It is important to note that only social democracy (or some form of egalitarian liberalism with emphasized republican elements) can accommodate such reforms. My intention is not to present fully developed arguments since such a project would be outside the scope of this paper. Instead, we want to sketch possible directions for further discussion.

Note that the objection from the previous section (science being directed to serve interests of the capital and not the interests of the people) corresponds to the one put forward earlier by J. Ranciere and emphasized at the beginning of this paper: (2) contemporary liberal democracies are defective because they allow wealth and economic power of groups and individuals to influence public decision-making, making those with economic power an elite group. Relying on influential work of John Rawls (Rawls, 2001) and his followers 
that embrace the idea of property-owning democracy (O'Neill, 2012; Thomas, 2012), we embrace the idea that budgeting of political campaigns should be restricted and controlled in order to remove economic power from political power. Furthermore, wealth should be redistributed to allow equal capability for participation in public decision-making for all members of a community (Marrone, 2003). This calls for distribution models that are even more egalitarian than that of an (American type) welfare state.

I have emphasized earlier that, in order to ensure that public deliberation efficiently tracks the truth, we must make people more competent and more interested in public issues. Note that this idea corresponds with another one of J. Ranciere's objections: (4) contemporary liberal democracies are defective because they allow and encourage social and economic conditions that make people inappropriate for decision-making on important issues, making those with certain characteristics thus acquired an inferior group. Starting from previously embraced idea of property-owning democracy, we claim that the state should secure both material and educational prerequisites that will allow people to actively participate in the decision-making processes. The state should encourage people to participate in public deliberation. We find that this former claim is not incompatible with Rawlsian idea of liberal neutrality (Rawls 2001, Baccarini \& Zelić, 2010), i.e. the idea that the liberal state should not promote any particular "conception of the good". If political participation is not seen as a part of any particular conception of the good, but instead as a prerequisite for stability of a well-ordered democratic society (or as a prerequisite for realization of deliberative democracy's truth-tracking potential), the liberal state can justify policies that aim to promote participation in collective decision-making (White, 2012).

\section{CONCLUSION}

The connection between knowledge and social power has been neglected in the contemporary Anglo-American epistemology. Since it had a relativistic, postmodern outlook, it was unimportant for individualist framework and rational idealization of analytic philosophy. Ranciere's important contribution is in placing reason and knowledge in the context of social power. However, his suspicion of the "reason per se" and tendency to reduce it to the operation of social power eradicated the distinction between what we have a reason to believe and what mere relations of social power are doing to our thinking.

In this paper we wanted to present the claim that one does not have to embrace postmodernist idea of reducing reason to relations of power in order to present a substantial critique of our contemporary society. Furthermore, one does not have to base egalitarian democracy on postmodernist ideas that reject the truth-tracking potential of democratic procedures - egalitarian democracy is perfectly compatible with the idea of truth in politics. Even more so, as we have noted earlier, it is the only political system that can, by ensuring public participation and wide access to education, establish a decision-making procedure with adequate truth-tracking potential. 


\section{REFERENCES}

Baccarini, E., \& Zelić, N. (2010). Rawlsova teorija pravednosti i pitanje istine. [Rawls' theory of justice and the question of truth]. Filozofska istraživanja, 121(1). 65-83.

Cerovac, I. (2013). Epistemička deliberativna demokracija [Epistemic Deliberative Democracy]. In: I. Cvejić (Ed.). Mišljenje, verovanje, delanje - filozofkso orijentisanje u političkoj situaciji [Thinking, Believing, Acting Philosophical Orientation in Political Situation] (pp. 69-99). Beograd: USF Beograd.

Christiano, T. (2004). The Authority of Democracy. The Journal of Political Philosophy, 12(3). 266-90.

Cohen, J. (1986). An Epistemic Conception of Democracy. Ethics 97(1). 26-38.

Delli Carpini, M.X. (2005). An Overview of the State of Citizens' Knowledge About Politics, In: M.S. McKinney, L.L. Kaid, D.G. Bystrom, \& D.B. Carlin (Eds.). Communicating politics: Engaging the public in democratic life. New York: Peter Lang.

Estlund, D. (1997). Beyond Fairness and Deliberation: The Epistemic Dimension of Democratic Authority. In: J. Bohman, \& W. Rehg (Eds.) (1997). Deliberative Democracy: Essays on Reason and Politics (pp. 173-204). London: The MIT Press.

Estlund, D. (2009a). Democratic Authority: A Philosophical Framework. Princeton: Princeton University Press.

Estlund, D. (2009b). Epistemic Proceduralism and Democratic Authority. In: R. Tinnevelt, \& R. Geenens (Eds.). Does Truth Matter? Democracy and Public Space (pp. 15-27). Dordrecht: Springer.

Festenstein, M. (2009). Truth and Trust in Democratic Epistemology. In: R. Tinnevelt, \& R. Geenens (Eds.). Does Truth Matter? Democracy and Public Space (pp. 69-80). Dordrecht: Springer.

Fricker, M. (2007). Epistemic Injustice: Power and the Ethics of Knowing. Oxford: Oxford University Press.

Habermas, J. (1976). Legitimation crisis. London: Heinemann Educational Books.

Kursar, T., \& Vukojević, I. (2013). Varijante postdemokracije [Variations of Postdemocracy]. Političke perspektive, 02. 23-38.

Marrone, P. (2003). Un'introduzione alle teorie della giustizia [An Introduction to Theories of Justice]. Milano: Mimesis.

Mešanović, A. (2013). Deliberationa demokracija: Epistemički proceduralizam [Deliberative Democracy: Epistemic Proceduralism]. Unpublished master's theses. University of Rijeka, Croatia.

Misak, C. (2009). Truth and Democracy: Pragmatism and the Deliberative Virtues. In: R. Tinnevelt, \& R. Geenens (Eds.). Does Truth Matter? Democracy and Public Space (pp. 29-39). Dordrecht: Springer.

O'Neill, J. (2002). The Rhetoric of Deliberation: Some problems in Kantian Theories of Deliberative Democracy. Res Publica, 8. 249-268.

O'Neill, M. (2012). Property Owning Democracy, Liberal Republicanism, and the Idea of an Egalitarian Ethos. In: T. Williamson (Ed.) (2012). Property-Owning Democracy: Rawls and Beyond (pp. 75-100). Chichester: Wiley-Blackwell. Price, H. (2003). Truth as Convenient Friction. Journal of Philosophy, 100. 167-190.

Prijić-Samaržija, S. (2013). Epistemic Value of Procedural Fairness. Upublished lecture. Symposium of Fabienne Peter's Democratic Legitimacy. University of Rijeka, Croatia.

Ranciere, J. (1998). Disagreement: Politics and Philosophy. Minneapolis: University of Minnesota Press.

Ranciere, J. (2009). Hatred of Democracy. London: Verso.

Rawls, J. (1999). A Theory of Justice. Oxford: Oxford University Press.

Rawls, J. (2001). Justice as Fairness: A Restatement. Cambridge: Harvard University Press.

Schmitt, C. (1932). Legality and Legitimacy. Durham: Duke University Press.

Sustain, C. (2006). Infotopia: How Many Minds Produce Knowledge. Oxford: Oxford University Press.

Thomas, A. (2012). Property Owning Democracy, Liberal Republicanism, and the Idea of an Egalitarian Ethos. In: T. Williamson (Ed.) (2012). Property-Owning Democracy: Rawls and Beyond (pp. 1010-128). Chichester: WileyBlackwell.

White, S. (2012). Property-Owning Democracy and Republican Citizenship. In: T. Williamson (Ed.) (2012). Property-Owning Democracy: Rawls and Beyond (pp. 129-146). Chichester: Wiley-Blackwell. 